\title{
Integrating Mobile Phones into the EFL Foundation Year Classroom in King Abdulaziz University/KSA: Effects on Achievement in General English and Students' Attitudes
}

\author{
Abdulhafeth A. Khrisat ${ }^{1} \&$ Salameh Saleem Mahmoud ${ }^{2}$ \\ ${ }^{1}$ Faculty of Arts, King Abdulaziz University, Saudi Arabia \\ ${ }^{2}$ English Language Institute, King Abdulaziz University, Saudi Arabia \\ Correspondence: Salameh Saleem Mahmoud, English Language Institute, King Abdulaziz University, Jeddah, \\ Saudi Arabia. Tel: 545-782-715. E-mail: nmgad2014@yahoo.com
}

\author{
Received: May 13, 2013 Accepted: June 7, 2013 Online Published: July 4, 2013 \\ doi:10.5539/elt.v6n8p162 URL: http://dx.doi.org/10.5539/elt.v6n8p162
}

\begin{abstract}
This study investigates the effect of ten teaching English as a foreign language (TEFL) oriented features of mobile phones in the English language classroom on the achievement of foundation-year students in King Abdulaziz University (KAU) in General English. The study also explores students' attitudes towards this new method of teaching. The study uses an experimental design where the control group is taught through the strategies used in ELI, whereas the experimental group is taught through the same strategies used in the control group in addition to mobile phones. The independent variable is using ten features of mobile phones in the EFL classroom and the dependent variable is the foundation-year students' achievement in general English. Forty male students of the foundation year at level two are assigned for the control group as well as the experimental one. The tools of the study are: A pre-test to ensure the equivalency of the two groups before conducting the experiment, a post test to see if there are any statistically significant differences in students' achievement in general English that are attributed to mobile phones, and a questionnaire to see students' attitudes towards using mobile phones in the English as a foreign language (EFL) classroom. The results of the t-test showed differences in the mean scores in favor of the experimental group, but these differences were not statistically significant at $\alpha$ $=0.5$. The analysis of the questionnaire showed positive attitudes toward using mobile phones in the classroom. The study concludes with recommendations about training students and teachers on the academic use of mobile phones and reinforcing the attitudes of students toward using them in the EFL classroom.
\end{abstract}

Keywords: Kingdom of Saudi Arabia (KSA), King Abdulaziz University (KAU), English Language Institute (Eli), Foundation Year, Mobile Phone, Levels, Modules, MALL, SMS

\section{Introduction}

Technological development has contributed to the use of new devices in the field of education. Mobile phone-based learning as an instructional approach has assumed an increasing attention in the field of English as a foreign language. Recent research has dealt with the use of mobile phones in the learning and teaching of EFL. The increasing spread of mobile phones among people especially the new generation which amounts to $100 \%$ in many countries calls for a bad need to look for constructive uses of this technology instead of being a very destructive distracter. O'Conner, (2005) discussed the idea of using mobile phones constructively instead of fighting with students over playing with their mobiles in the class. Moris, (2011) explores the ways that technology, especially laptop computers and mobile phones, may be incorporated in the EFL classroom to enhance learning and lower the affective filter of male Saudi Arabian university students. Reinders, (2010) introduces few practical uses of mobile phones in the English class that are emphasized by the recent generation of researchers. Such uses are using the notes feature to collect everyday language, the camera feature to take pictures of texts, the Voice Memo Recorder feature to record conversations outside the classroom, the Text Messaging feature to reinforce vocabulary learning, the Text Messaging feature for circular writing ...etc. These uses are expected to break the routine of traditional classrooms and to solve the problem of the lack of motivation which is a critical issue in the Saudi environment. 


\section{Review of Literature}

\subsection{Theoretical Background}

Over the last few years, there has been much interest in using mobile phones in the EFL/ESL classroom. This interest was a response to the wide spread of these smart phones and multi facilities they have on one hand and the lack of motivation on the part of students on the other hand. The European Network of Excellence in Technology Enhanced Learning most recently brought together forty researchers in mobile learning in a conference titled "Kaleidoscope" to discuss the implications of adopting mobile phones as a learning tool (Sharples, 2006a as cited in Trucano, 2009). Examples of the increased attention are popping up all over the world. A quick search for mobile phones in the ERIC database yields over 275 articles. It is not surprising that there is an international association for mobile learning (Trucano, 2009).

"Toys to Tools" written by Kolb, (2008) serves as a guide to the educational use of mobile phones. Kolb provides practical suggestions for what to teach and how to teach. She sees mobile phones as a powerful technology available for students and addresses the issues that have caused problems that accompany using mobile phones in the classroom and provides suggestions for avoiding these problems. In her opinion, ignoring a technology that students willingly and actively use is not a wise decision. Mini lessons and powerful resources throughout the book can be used easily and appropriately for almost any grade level and are designed to enhance learning inside and outside of the classroom. $\mathrm{Sad}_{2}$ (2008) and Maclean $_{2}$ (2010) mentioned some ideas of students' using roles, rehearsing their parts and finally recording their performance.

\subsection{The Importance of Using Mobile Phones in the EFL/ESL Classroom}

Using mobile phones in the EFL classroom to involve uncooperative and unmotivated students has been a rich environment for investigation over the last two decades. Fisher and Baired (2007) shared results from an mlearning design experiment and analysis from a student survey at the National College of Ireland. Qualitative edata support their hypothesis that $\mathrm{m}$ - learning technologies can provide a platform for active learning, collaboration and innovation in higher education. Al-Shehri (2011) suggested that mobile technology and social networking have the potential to establish learning practices that are not only based on learners' needs and experiences, but they can also involve learners in the overall learning process that sometimes goes beyond the classroom, in addition to creating authentic learning opportunities. Begum (2011) explored the potential of mobile phone usages as instructional tools in EFL classroom of Bangladesh. The researcher conducted a case study on Jahangirnagar University of Bangladesh to find out the benefits and challenges of using mobile phones in the classroom. Some short message service (SMS) based class tests were conducted where the teachers sent mobile SMS to students as a means of instruction for teaching appropriate use of prepositions. To find out the efficacy of SMS based classes, a test was taken via SMS and students' replies were checked and they were given feedback through SMS. After that, students' and teachers' opinions regarding the mobile phone usages, its benefits and inhibiting factors for the implementations in the EFL classroom were collected through students' questionnaire, teachers' interviews and classroom observation reports. The research results imply that the mobile phone has great potential as an instructional tool despite some challenges that can be solved by the authority and teachers and by changing the ethical point of view that considers mobile phones as a disturbing factor in the classroom.

Baleghizadeh and Oladrostan (2012) investigated improving the grammatical knowledge of EFL students using mobile phones. The students in the experimental group recorded their voice on their mobile phones and as an out of class assignment analyzed their spoken mistakes and commented on them in the following session. The results were in favor of the experimental group. Miangah and Nezarat (2012) pointed out that the main characteristics of mobile learning are recognized as potential for the learning process to be personalized, spontaneous, informal and continuous. Despite the fact that learning through mobile phones may take longer time compared to computers, the learners enjoy greater sense of freedom of time and place, so that they can take the advantage of spare time to learn a second language whenever and wherever they want. In contrast to classroom learning, in Mobile Assisted Language Learning (MALL), there is no need for the learners to sit in a classroom or at a computer to get learning materials. In fact, MALL can be considered an ideal solution to language learning barriers in terms of time and place.

\subsection{Students'Attitudes towards Using Mobile Phones}

A positive attitude towards using mobile phones in the classroom is a very important factor for getting the benefits of this wide spread device.Teachers and students should believe that mobile phones can be important tools in revolutionizing the teaching and learning process through adding fun and life to the classroom. To know about students' attitudes toward using mobile phones and their achievement on certain strategies, (Thornton and 
Houser (2005) conducted a three-step study. First, they polled 333 Japanese university students regarding their use of mobile phones. Second, they mailed 100-word English vocabulary lessons at timed intervals to the mobile phones of 44 Japanese university students, hoping to promote regular study. Compared to students urged to regularly study identical materials on paper or Web, students receiving mobile e-mails learned more; moreover, seventy-one percent of the subjects preferred receiving these lessons on mobile phones rather than PCs. Ninety-three percent felt that it was a valuable teaching method. Third, they created a Web site explaining English idioms. Student-produced animation that shows each idiom's literal meaning and a video showing the idiomatic meaning. Textual materials include an explanation, script, and quiz. Thirty-one Japanese college sophomores evaluated the site using video-capable mobile phones, finding few technical difficulties, and rating highly its educational effectiveness. Khwaileh and Al-Jarrah, (2010) surveyed the Faculty of Educational Sciences at the University of Jordan. A questionnaire consisted of 30 statements developed by the researchers was used for data collection. The results of the study showed that there were no negative opinions toward M-learning held by the participants. Also, the results of the study showed that the students are willing to use M-learning and that they believe that M-learning has a lot of advantages. Willard, (2011) conducted a study to determine students behaviors with mobile phone use regarding EFL classroom activities. A questionnaire was given to 200 Bangkok university students in order to learn how the students were currently using their mobile phones now and in the future. The results have suggested students' preference for using mobile phones for various activities. Wang; Chen; \& Fang, (2011) investigated the integration of an M-learning activity into a traditional EFL classroom by looking at students' attitudes, technological readiness, perceived learning, and perceived appropriateness of the activity design. Findings of the study indicated that students enjoyed the activity. They found the activity interesting, inspiring, and effective for their English learning. Students had no technological anxieties related to mobile phone use.

\subsection{Disadvantages of Using Mobile Phones in the EFL/ESL Classroom}

Mobile phones, like any new invention are not free of disadvantages. Few people say that using them is a loss and theft and potential bullying, distracting and interruption. Taking photos of tests and passing them on to others, texting answers of texts to other students, spreading rumors fast, privacy issues with teachers, having personal numbers of pupils and vice versa are among the disadvantages for using mobile phones in the classroom, (Atwell 2012). Furthermore, most of the modern multi- facility mobile phones are not cheap to buy; these can cost anywhere from $\$ 100$ to more than $\$ 500$. Also, technology changes and advances very quickly. To take advantage of all that technology has to offer, one needs to upgrade his/her mobile device frequently. Additionally, there are typically monthly data charges with one's mobile provider so if one needs to download large files that take a long time, his/her monthly charges could be quite high. The size of the device is also a disadvantage for two reasons. First, because they are small, these devices are easily lost or stolen. Second, the screen size is quite small and can result in eye-strain for people using them for long periods of time. Also, the amount of information that can be displayed on the screen at one time is quite small. Furthermore, the battery life for mobile devices ranges from about two to four hours of use and once it runs out, one must plug it in to recharge and there is no longer any mobile to use. The buttons on the keypad or stylus pens are small and can be tricky for some people to manipulate. There are attachable keyboards available for some devices but these are also small and they can be difficult to use and cost money.

\section{Methodology}

\subsection{Participants}

All the new students at King Abdulaziz University (KAU) sit for a placement English language test upon joining the foundation year to know which level they are going to start with. In the foundation year, students are supposed to finish successfully four English language levels if they are classified level one which is for beginners. The sample of this study consists of forty EFL foundation-year male students. They started with level two which means they are classified as intermediate and should study levels two, three and four. While conducting the study, they were in their first module- the seven weeks each quarter usually lasts- in the academic year 2012/2013. The students have common features like having Arabic language as their mother tongue, English as a foreign language and everyone is Saudi by birth. Their age ranges from 18-19. Two instructors of English language from the English Language Institute (Eli) helped in conducting the study. The control group instructor received no training as he is following the system followed in Eli in terms of teaching strategies, whereas the experimental group instructor received training on how to apply the mobile features in the TEFL classroom. Both instructors have nearly similar experience and the same qualifications. 


\subsection{Research Design}

The study uses an experimental design with one control group and one experimental group. The control group is taught using strategies other than integrating mobile phones in the EFL classroom; whereas the experimental group was taught using the same strategies in the control group in addition to integrating ten mobile phone TEFL- oriented features. The independent variable of the study is using the ten mobile phone TEFL oriented features mentioned earlier in the introduction. .Details about these strategies are in appendix (1). The dependent variable is students' achievement in general English. The experiment continued for seven weeks - the period each module usually lasts. After the experiment, students answered a questionnaire about their attitudes towards using mobile phones in the English language classroom, and then they sat for the post test.

To apply the ten mobile-based features over the seven weeks, the students in the experimental group were asked to do the following on weekly basis: Use the notes feature in their mobile phones to write any sentence, vocabulary item, proverb, idiom or grammatical structure they come across in or outside the classroom., take pictures of texts, familiar or unfamiliar things (buildings, accidents, cars, markets, people...etc), use the voice memo recorder feature to record interviews, lectures, news on TV or short stories, send messages to their teacher containing a summary of the vocabulary items they learn on daily basis. In a group-based writing activity, the first group messages the first sentence to the second group who messages two sentences to the third group, who messages three sentences to the fourth group. Then the fourth group messages four sentences to the fifth group, who messages the whole paragraph of five sentences to their instructor, use the dictionaries installed in their mobile phones to look up meanings of new words, receive listening and reading texts to prepare at home for further exploitation in the class and finally browse the internet for further consolidation-worksheets, exercises, enriching materials, games, activities or any further exposure to language as long as it matches with the Saudi culture. The materials students collect or receive from their instructor using their mobiles are used by their instructor as pre (reading, writing, speaking or listening) activities. (For more examples of using the ten mobile based features, see Appendix One.)

\subsection{Questions of the Study}

The study answered two questions:

1-Are there any statistically significant differences in students' achievement in general English that are attributed to integrating mobile phones in the English language classroom?

2-What are students' attitudes towards integrating mobile phones in the English language classroom?

\subsection{Instruments}

The tools that were used in the study are: A general English language test covering the four skills and sub-skills, validated by a committee of experts of varying experiences and piloted on a group of students outside the sample. The paired sample correlation of the experimental group and control group before and after the treatment was $(0.84)$ and $(0.85)$ respectively. This test was used as a pre-test to ensure the equivalency of the control and the experimental groups and as a post test to see if there is any statistically significant difference that is attributed to integrating ten mobile phone TEFL-oriented features in the EFL classroom. A survey questionnaire developed by the researchers written in English and translated into Arabic was utilized to collect data in order to investigate foundation year students' attitudes toward M-learning. The questionnaire consisted of twenty (20) positively and negatively phrased statements to prevent any response set. Several items used in other questionnaires from other studies were reformulated for this study to meet its purpose. A five-point Likert scale was used ( $5=$ strongly agree $-1=$ strongly disagree) and the questionnaire was completed by the participants. The first draft of the questionnaire was sent to a group of referees to determine its relevancy and validity. Minor changes were suggested by the referees. Upon re-examination of a second draft, consensus among the referees on the questionnaire's design and validity indicated a strong validation of the statements used in the questionnaire. A correlation coefficient value (0.84) was used to test the internal reliability of the questionnaire and it showed an acceptable reliability value. The statements of the questionnaire were categorized in three sections as follows:

* Statements from 1-6, to measure "the willingness to use M-learning".

* Statements from 7-13, to measure "the advantages of M-learning that support using it".

* Statements from 14-20, to measure "the disadvantages of M-learning that hinder its use".

\section{Results of the Study}

\subsection{Results Related to Question 1}

1-Is there any statistically significant difference in students' achievement in general English that is attributed to 
integrating mobile phones in the English language classroom?

Table 1. Mean scores of the Experimental and the Control Groups on the Pre and Post Tests Paired Sample Statistics

\begin{tabular}{clcc}
\hline Mean & N & Std. Deviation & Std.Error Mean \\
\hline Pair 1 before CA1 53.0000 & 20 & 17.60981 & 3.93767 \\
after CA1 67.1000 & 20 & 13.92801 & 3.11440 \\
Pair 2 before AE1 54.1 & 20 & 11.97486 & 2.67766 \\
after AE1 60.7000 & 20 & 11.77017 & 2.63189 \\
\hline
\end{tabular}

Table 1 shows the mean scores of the Experimental Group which was given the name (CA1) and the Control Group which was given the name (EA1) on the pre test 53.00 and 54.15 respectively and the mean scores of the Experimental Group and the Control group on the post test 67.10 and 60.70 respectively. The very close means on the pre test show that the two groups are almost the same which means that any significant difference in the means on the post-test will be attributed to the treatment that is using or not using mobile phones in the L2 classroom.

Table 2. Paired Samples Correlation

\begin{tabular}{llccc}
\hline & $\mathrm{N}$ & correlation & sig \\
\hline Pair 1 & before CA1 \& after CA1 & 20 & .845 & .000 \\
Pair 2 & before AE1 \& after EA1 & 20 & .857 & .000 \\
\hline
\end{tabular}

Table 2 shows the correlation between the experimental group before and after the treatment 0.84 and the correlation between the Control Group before and after the treatment 0.85 which is very strong and accepted in such cases.

Table 3. Paired Differences

Paired Sample Tests

Paired Differences

Mean STD. Deviation Std, Error
Mean Lower Upper $t$ df sig.

95\% Confidence Interval of the Differences

\begin{tabular}{lccccccc} 
Mean & STD. Deviation Std, Error & & & \\
& & & Mean & Lower & Upper & t & df $\begin{array}{c}\text { sig. } \\
\text { (2-tailed) }\end{array}$ \\
\hline Pair 1 before CA1- after CA1 4.1000 & 9.46406 & 2.11623 & 18.52932 & -9.67068 & -6.663 & 19 & .000 \\
Pair 2 before AE1-after AE1 6.5500 & 6.36169 & 1.42252 & -9.52736 & -3.57264 & 4.605 & 19 & .000 \\
\hline
\end{tabular}

Table 3 shows the differences between the mean scores of the experimental group and the control group before and after the treatment (14.10 and 6.55)

Table 4. Independent Sample Test

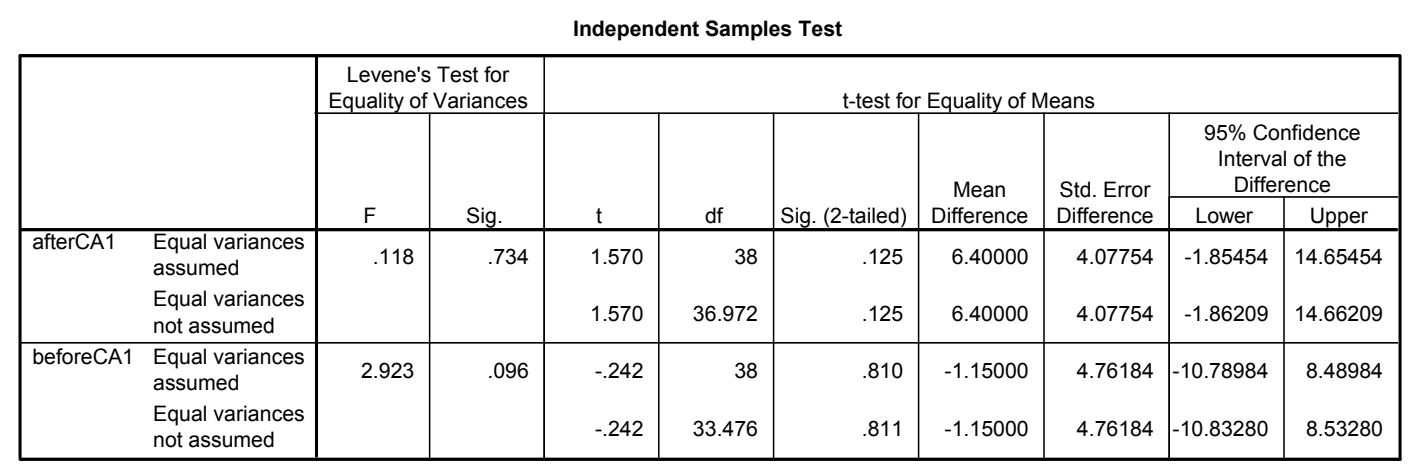

Table 4 shows that although there are differences in the mean scores on the post test in favor of the experimental group $(14,10)$, the significance (2-tailed) on the $\mathrm{t}$ - test for equality of means $(0.125)$ is bigger than $(0.05)$. This 
shows that the difference in the mean scores of the experimental group before and after the treatment is not statistically significant.

\subsection{Results Related to Question 2}

What are students' attitudes towards integrating mobile phones in the English language classroom?

As shown earlier in the methodology of the study, the questionnaire consists of 20 items divided into three categories: 1-6 about the willingness to use mobile learning, 7-13 about the advantages of mobile learning and 14-20 about the disadvantages of mobile learning. A quick look at the case processing summaries shows that the total of the valid cases is $100 \%$ and of the missing cases is $0 \%$. The frequency and the percentages of respondents in the three sub-categories were as follows:

Table 5. First group of questions, 1-6: Students' Willingness to use the mobile for learning in the EFL classroom

\begin{tabular}{|c|c|c|c|c|c|c|c|c|c|c|c|}
\hline \multirow[t]{2}{*}{$\begin{array}{l}\text { No } \\
.\end{array}$} & \multirow[t]{2}{*}{ Statement } & \multicolumn{2}{|c|}{ Strongly Disagree } & \multicolumn{2}{|c|}{ Disagree } & \multicolumn{2}{|c|}{ Can't Tell } & \multicolumn{2}{|c|}{ Agree } & \multicolumn{2}{|c|}{$\begin{array}{l}\text { Strongly } \\
\text { Agree }\end{array}$} \\
\hline & & Frequency & Percent & $\begin{array}{l}\text { Fre } \\
\text { que } \\
\text { ncy }\end{array}$ & $\begin{array}{l}\text { Percen } \\
t\end{array}$ & $\begin{array}{l}\text { Fre } \\
\text { que } \\
\text { ncy }\end{array}$ & $\begin{array}{l}\text { Perc } \\
\text { ent }\end{array}$ & $\begin{array}{l}\text { Freq } \\
\text { uenc } \\
\text { y }\end{array}$ & $\begin{array}{l}\text { Perc } \\
\text { ent }\end{array}$ & $\begin{array}{l}\text { Freq } \\
\text { uenc } \\
\text { y }\end{array}$ & $\begin{array}{l}\text { Perc } \\
\text { ent }\end{array}$ \\
\hline 1 & $\begin{array}{l}\text { Using the mobile gives me a } \\
\text { better chance to learn more } \\
\text { than the lecture }\end{array}$ & 4 & $10 \%$ & 12 & $30 \%$ & 4 & $10 \%$ & 8 & $20 \%$ & 12 & $30 \%$ \\
\hline 2 & $\begin{array}{l}\text { Using mobile learning } \\
\text { makes learning easier. }\end{array}$ & 5 & $12.5 \%$ & 11 & $27.5 \%$ & 6 & $15 \%$ & 9 & $\begin{array}{l}22 . . \\
5 \%\end{array}$ & 11 & $\begin{array}{l}27.5 \\
\%\end{array}$ \\
\hline 3 & $\begin{array}{l}\text { Using M-Learning makes } \\
\text { learning an attractive } \\
\text { experience. }\end{array}$ & 3 & $7.5 \%$ & 10 & $25 \%$ & 7 & $\begin{array}{l}17.5 \\
\%\end{array}$ & 9 & $\begin{array}{l}22.5 \\
\%\end{array}$ & 11 & $\begin{array}{l}27.5 \\
\%\end{array}$ \\
\hline 4 & $\begin{array}{l}\text { Using the mobile should be } \\
\text { gradual. }\end{array}$ & 0 & $.0 \%$ & 4 & $10 \%$ & 8 & $20 \%$ & 14 & $35 \%$ & 14 & $35 \%$ \\
\hline 5 & $\begin{array}{l}\text { It is possible to use the } \\
\text { mobile as a learning tool in } \\
\text { the future. }\end{array}$ & 1 & $2.5 \%$ & 2 & $5 \%$ & 7 & $\begin{array}{l}17.5 \\
\%\end{array}$ & 13 & $\begin{array}{l}32.5 \\
\%\end{array}$ & 17 & $\begin{array}{l}42.5 \\
\%\end{array}$ \\
\hline 6 & $\begin{array}{l}\text { Using the mobile is easier } \\
\text { for students than other } \\
\text { methods. }\end{array}$ & 1 & $2.5 \%$ & 7 & $17.5 \%$ & 6 & $15 \%$ & 12 & $30 \%$ & 14 & $35 \%$ \\
\hline
\end{tabular}

Table 5 shows the number of respondents and the percentages in Likert five-point scale. For item one "Using the mobile gives me better chance to learn more than the lecture", 16 respondents $(40 \%)$ disagreed (strongly disagree and disagree), 4 respondents (10\%) were neutral (can't tell) and 20 respondents $(50 \%)$ agreed (agree and strongly agree). For the second statement "Using mobile learning makes learning easier" 16 (40\%) disagreed, 4 $(10 \%)$ were neutral and $20(50 \%)$ agreed. For the third statement "Using M-Learning makes learning an attractive experience". 13 (32.5\%) disagreed, 7 (17.5\%) were neutral and $20(50 \%)$ agreed. The fourth statement "Using the mobile should be gradual." 4 (10\%) disagreed, 8 (20\%) were neutral and $28(70 \%)$ agreed. The fifth statement "It is possible to use the mobile as a learning tool in the future." $3(7.5 \%)$ disagreed, $7(17.5 \%)$ were neutral and $30(75 \%)$ agreed. The sixth item "Using the mobile is easier for students than other methods", 8 $(20 \%)$ disagreed, $6(15 \%)$ were neutral and $26(65 \%)$ agreed. A summary of the percentages of the six items shows that $25 \%$ of the sample responded negatively to the six items of the first subgroup that is using the mobile in the EFL classroom, whereas $15 \%$ were neutral and $60 \%$ responded positively

Table 6. Second group of questions, 7-12: The Advantages of Using M-Learning

\begin{tabular}{|c|c|c|c|c|c|c|c|c|c|c|c|}
\hline \multirow[t]{2}{*}{ No. } & \multirow[t]{2}{*}{ Statement } & \multicolumn{2}{|c|}{$\begin{array}{l}\text { Strongly } \\
\text { Disagree }\end{array}$} & \multicolumn{2}{|c|}{ Disagree } & \multicolumn{2}{|c|}{ Can't Tell } & \multicolumn{2}{|l|}{ Agree } & \multicolumn{2}{|c|}{$\begin{array}{l}\text { Strongly } \\
\text { Agree }\end{array}$} \\
\hline & & $\begin{array}{l}\text { Freque } \\
\text { ncy }\end{array}$ & $\begin{array}{l}\text { Percen } \\
t\end{array}$ & $\begin{array}{l}\text { Fre } \\
\text { que } \\
\text { ncy }\end{array}$ & $\begin{array}{l}\text { Perce } \\
\text { nt }\end{array}$ & $\begin{array}{l}\text { Freq } \\
\text { uenc } \\
\mathrm{y}\end{array}$ & $\begin{array}{l}\text { Perce } \\
\text { nt }\end{array}$ & $\begin{array}{l}\text { Freq } \\
\text { uenc } \\
y\end{array}$ & $\begin{array}{l}\text { Perc } \\
\text { ent }\end{array}$ & $\begin{array}{l}\text { Freq } \\
\text { uenc } \\
\text { y }\end{array}$ & $\begin{array}{l}\text { Perc } \\
\text { ent }\end{array}$ \\
\hline 7 & $\begin{array}{l}\text { Using the mobile increases } \\
\text { students' ideas and knowledge }\end{array}$ & 1 & $.2 .5 \%$ & 5 & $12.5 \%$ & 4 & $10 \%$ & 13 & $\begin{array}{l}32.5 \\
\%\end{array}$ & 17 & $\begin{array}{l}42.5 \\
\%\end{array}$ \\
\hline 8 & Using the mobile increases & 3 & $7.5 \%$ & 6 & $15 \%$ & 5 & 12.5 & 15 & 37.5 & 11 & 27.5 \\
\hline
\end{tabular}




\begin{tabular}{|c|c|c|c|c|c|c|c|c|c|c|c|}
\hline & $\begin{array}{l}\text { students' chances for learning } \\
\text { more than traditional learning } \\
\text { which is limited by time and } \\
\text { place }\end{array}$ & & & & & & $\%$ & & $\%$ & & $\%$ \\
\hline 9 & $\begin{array}{l}\text { M-Learning is cheaper than } \\
\text { traditional methods of learning }\end{array}$ & 1 & $.2 .5 \%$ & 3 & $7.5 \%$ & 9 & $\begin{array}{l}22.5 \\
\%\end{array}$ & 15 & $\begin{array}{l}37.5 \\
\%\end{array}$ & 12 & $30 \%$ \\
\hline 10 & $\begin{array}{l}\text { Using the mobile gives students' } \\
\text { a chance for wide range of } \\
\text { learning }\end{array}$ & 2 & $.5 \%$ & 4 & $10 \%$ & 3 & $7.5 \%$ & 17 & $\begin{array}{l}42.5 \\
\%\end{array}$ & 14 & $35 \%$ \\
\hline 11 & $\begin{array}{l}\text { M-Learning can facilitate } \\
\text { English learning }\end{array}$ & 3 & $7.5 \%$ & 4 & $10 \%$ & 7 & $\begin{array}{l}17.5 \\
\%\end{array}$ & 14 & $35 \%$ & 12 & $30 \%$ \\
\hline 12 & M-Learning saves time & 2 & $5 \%$ & 6 & $15 \%$ & 6 & $15 \%$ & 13 & $\begin{array}{l}32.5 \\
\%\end{array}$ & 13 & $\begin{array}{l}32.5 \\
\%\end{array}$ \\
\hline 13 & $\begin{array}{l}\text { M-learning contributes much to } \\
\text { self-learning }\end{array}$ & 0 & $.0 \%$ & 4 & $10 \%$ & 5 & $\begin{array}{l}12.5 \\
\%\end{array}$ & 17 & $\begin{array}{l}42 . \\
5 \%\end{array}$ & 14 & $35 \%$ \\
\hline
\end{tabular}

Table 6 shows the number of respondents and the percentages in Likert five-point scale. For item seven "Using the mobile increases students' ideas and knowledge ", 6 respondents (15\%) disagreed, 4 respondents $(10 \%)$ were neutral and 30 respondents (75\%) agreed. For the eighth statement "Using the mobile increases students' chances for learning more than traditional learning which is limited by time and place" $9(22,5 \%)$ disagreed, $5(12.5 \%)$ were neutral and $26(65 \%)$ agreed. The ninth statement "M-Learning is cheaper than traditional methods of learning" $4(10 \%)$ disagreed, $9(22.5 \%)$ were neutral and $27(67.5)$ agreed. The tenth statement "Using the mobile gives students' a chance for wide range of learning" $6(15 \%)$ disagreed, $7(17.5 \%)$ were neutral and 31 (77.5) agreed. The eleventh statement "M-Learning can facilitate English learning." 5 (12.5\%) disagreed, 7 $(17.5 \%)$ were neutral and $26(65 \%)$ agreed. The twelfth item "M-Learning saves time ", 6 (15\%) disagreed, 6 $(15 \%)$ were neutral and $26(65 \%)$ agreed. The thirteenth item "M-learning contributes much to self-learning" $4(10 \%)$ disagreed, $5(12.5 \%)$ were neutral and $31(77.5 \%)$. A summary of the percentages of the seven items shows that $14.2 \%$ of the sample responded negatively to the seven items of the second subgroup that is "the advantages of using mobile phones in the EFL classroom", whereas $15.3 \%$ were neutral and $70.3 \%$ responded positively

Table 7. Third group of questions, 14-20: The Disadvantages of M-Learning

\begin{tabular}{|c|c|c|c|c|c|c|c|c|c|c|c|}
\hline \multirow[t]{2}{*}{ No. } & \multirow[t]{2}{*}{ Statement } & \multicolumn{2}{|l|}{$\begin{array}{l}\text { Strongly } \\
\text { Disagree }\end{array}$} & \multicolumn{2}{|l|}{ Disagree } & \multicolumn{2}{|c|}{ Can't Tell } & \multicolumn{2}{|c|}{ Agree } & \multicolumn{2}{|c|}{$\begin{array}{l}\text { Strongly } \\
\text { Agree }\end{array}$} \\
\hline & & $\begin{array}{l}\text { Frequen } \\
\text { cy }\end{array}$ & $\begin{array}{l}\text { Perc } \\
\text { ent }\end{array}$ & $\begin{array}{l}\text { Frequenc } \\
\mathrm{y}\end{array}$ & $\begin{array}{l}\mathrm{Pe} \\
\mathrm{rce} \\
\mathrm{nt}\end{array}$ & $\begin{array}{l}\text { Freque } \\
\text { ncy }\end{array}$ & $\begin{array}{l}\text { Perce } \\
\mathrm{nt}\end{array}$ & $\begin{array}{l}\text { Fre } \\
\text { que } \\
\text { ncy }\end{array}$ & $\begin{array}{l}\text { Per } \\
\text { cent }\end{array}$ & $\begin{array}{l}\text { Fre } \\
\text { que } \\
\text { ncy }\end{array}$ & $\begin{array}{l}\text { Per } \\
\text { cen } \\
t\end{array}$ \\
\hline 14 & $\begin{array}{l}\text { Battery life and small screen } \\
\text { make the cell-phone unreliable } \\
\text { to use. }\end{array}$ & 0 & $.0 \%$ & 10 & $\begin{array}{l}25 \\
\%\end{array}$ & 8 & $20 \%$ & 16 & $\begin{array}{l}40 \\
\%\end{array}$ & 6 & $\begin{array}{l}15 \\
\%\end{array}$ \\
\hline 15 & $\begin{array}{l}\text { Using cell phone for learning } \\
\text { purposes confuses me more } \\
\text { than it helps me }\end{array}$ & 8 & $20 \%$ & 12 & $\begin{array}{l}30 \\
\%\end{array}$ & 12 & $30 \%$ & 0 & $.0 \%$ & 8 & $\begin{array}{l}20 \\
\%\end{array}$ \\
\hline 16 & $\begin{array}{l}\text { M-learning requires significant } \\
\text { changes in the student' attitude. }\end{array}$ & 0 & $.0 \%$ & 2 & $\begin{array}{l}5 \\
\%\end{array}$ & 18 & $45 \%$ & 12 & $\begin{array}{l}30 \\
\%\end{array}$ & 8 & $\begin{array}{l}20 \\
\%\end{array}$ \\
\hline 17 & $\begin{array}{l}\text { M-learning courses hinder } \\
\text { contribution to classroom } \\
\text { discussions. }\end{array}$ & 2 & $\% 5$ & 10 & $\begin{array}{l}25 \\
\%\end{array}$ & 6 & $15 \%$ & 14 & $\begin{array}{l}35 \\
\%\end{array}$ & 8 & $\begin{array}{l}20 \\
\%\end{array}$ \\
\hline 18 & $\begin{array}{l}\text { M-learning may need training } \\
\text { for teachers and students. }\end{array}$ & 4 & $10 \%$ & 8 & $\begin{array}{l}20 \\
\%\end{array}$ & 4 & $10 \%$ & 14 & $\begin{array}{l}35 \\
\%\end{array}$ & 10 & $\begin{array}{l}25 \\
\%\end{array}$ \\
\hline 19 & $\begin{array}{l}\text { M-learning poses difficulty in } \\
\text { evaluating students' results and } \\
\text { performance indicators. }\end{array}$ & 4 & $10 \%$ & 10 & $\begin{array}{l}25 \\
\%\end{array}$ & 14 & $35 \%$ & 10 & $\begin{array}{l}25 \\
\%\end{array}$ & 2 & $5 \%$ \\
\hline 20 & $\begin{array}{l}\text { M-learning reduces teamwork } \\
\text { and collaboration between } \\
\text { students }\end{array}$ & 2 & $5 \%$ & 12 & $\begin{array}{l}30 \\
\%\end{array}$ & 6 & $15 \%$ & 12 & $\begin{array}{l}30 \\
\%\end{array}$ & 8 & $\begin{array}{l}20 \\
\%\end{array}$ \\
\hline
\end{tabular}


Table 7 shows the number of respondents and the percentages in Likert five-point scale. For item fourteen "Battery life and small screen make the cell-phone unreliable to use”,, 10 respondents (25\%) disagreed, 8 (20\%) were neutral and $22(55 \%)$ agreed. For the fifteenth statement "Using cell phone for learning purposes confuses me more than it helps me" revealed that $20(50 \%)$ disagreed, $12(30 \%)$ were neutral and $8(20 \%)$ agreed. The sixteenth statement "M-learning requires significant changes in the student' attitude" 2 (5\%) disagreed, 18 (45\%) were neutral and $18(45 \%)$ agreed. The seventeenth statement "M-learning courses hinder contribution to classroom discussions." 12 (30\%) disagreed, $6(15 \%)$ were neutral and $22(55 \%)$ agreed. The eighteenth statement "M-learning may need training for teachers and students." 12 (30) disagreed, 4 (10) were neutral and 24 (60\%) agreed. The nineteen item "M-learning poses difficulty in evaluating students' results and performance indicators." 13 (32.5) disagreed, $14(35 \%)$ were neutral and $13(32.5 \%)$ agreed. The twentieth item "M-learning reduces teamwork and collaboration between students" $14(35 \%)$ disagreed, $6(15 \%)$ were neutral and $20(50 \%)$ agreed. A summary of the percentages of the seven items shows that $25.3 \%$ of the sample responded negatively to the seven items of the third subgroup that is "the disadvantages of using mobile phones in the EFL classroom", whereas $21.3 \%$ were neutral and $45.3 \%$ responded positively.

\section{Analysis and Discussion}

\subsection{Limitations}

Although this research was carefully prepared, we are still aware of its limitations and shortcomings. First of all, the research was conducted over seven weeks which is not enough for the researcher to test the students' achievement in all the skills and sub skills of English language. It would be better if it was done over a long time. Second, the population of the experimental group is small, only twenty students who might not represent the majority of the students of the foundation year. Third, although the questionnaire was designed to measure the students' attitude towards the use of mobile phones, it seems not to provide enough evidence of the students' actual understanding of the serious academic use of this device. In addition, since the assessment through pre-test and post test was done with pen and paper, it may not have given a clear picture about the performance indicators which may be better shown through continuous assessment.

\subsection{Discussion}

The statistical analysis related to question 1 (Is there any statistically significant difference in students' achievement in general English that is attributed to integrating mobile phones in the English language classroom?) shows negative results. Although there are differences between the mean scores on the post test in favor of the experimental group, these differences are not statistically significant as the significance (2-tailed) on the t-test for equality of means $(0.125)$ is bigger that $(0.05)$. This result is not in accordance with the bulk of research about using mobile phones in the EFL/ESL classroom. In the researchers' view this refers to the following:

- $\quad$ Saudi students even at the university level mainly use mobile phones for communication and for fun-playing games and trying new applications, because they are always keen on having the latest brands of mobile phones. This makes them less responsive to any serious try to exploit this wide spread technology for formal academic purposes.

- Text messages form the highest percentage of students' communication which may be a very rich source for writing and reading practice. Unfortunately, these text messages are usually written in Arabic which leaves no space for using them in the EFL classroom.

- Saudi students have the habit of absenting themselves for the slightest reasons. Out of the eighty hours they are supposed to attend in each module, they are allowed to be absent for twenty one hours and most of them usually exceed this absence limit. This lenient procedure of dealing with the absence issue should be treated more seriously.

The reasons mentioned above form a barrier against applying new teaching strategies including the strategy applied in this research. The mobile oriented features mentioned earlier need to be practiced on daily bases over a reasonably enough period of time so that they affect achievement. This becomes more urgent in teaching languages as they rely mainly on the amount of exposure and engagement.

The statistical analysis related to question 2 (What are students' attitudes towards integrating mobile phones in the English language classroom?) shows positive attitudes towards using the mobile phone in the EFL classroom. For the first category "students' willingness to use mobile phones in the classroom for ELT purposes", the percentage of respondents who answered either "agree or strongly agree" was $60 \%$ compared to those who disagreed or strongly disagreed (25\%) and neutral students who coudn't tell $(15 \%)$. This result reveals the fact 
that foundation-year students at King Abdulaziz University are really willing to use mobile learning. This positive attitude may refer to the fact that almost all students know how to use mobile phones and they use them on daily basis. This makes them show positive attitudes towards this wide spread device. This result agrees with the findings of other researchers Thornton and Houser (2005), Khwaileh and Al-Jarrah (2010), Willard (2011), Wang, Chen and Fang (2011)) that students become willing to use technology if they are already familiar with it in advance.

For the second category "advantages of using mobile phones in the EFL classroom", the percentage of respondents who answered either agree or strongly agree was $70.3 \%$ compared to those who answered disagree or strongly disagree (14.2\%) and neutral students who coudn't tell $(15.3$. This result means there is a general agreement among the students who recognize the importance of $\mathrm{M}$ learning and feel its advantages in the EFL classroom. Such result is very important for the decision makers in King Abdulaziz University who will consider it as a source of support and encouragement to adopt M. Learning.

For the third category "the disadvantages of using mobiles in the EFL classroom" the percentage of respondents who answered either agree or strongly agree was $45.3 \%$ compared to those who answered disagree or strongly disagree $(25.3 \%)$ and neutral students who coudn't tell (21.3\%). As the results show, those who coudn't tell are more than in any of the first two categories which means there is a lack of understanding of the nature of the disadvantages of using mobile phones in the classroom. In addition, students in KSA usually have the most upto-date brands of mobile phones with the best facilities and the least disadvantages. This makes them unaware of the barriers of using mobile phones in the EFL classroom.

This positive attitude towards the three categories of the questionnaire refers to Saudi students' addiction to use mobile phones especially for non-academic purposes. They look at the mobile as a toy used for playing games and exchanging of videos, pictures, films and songs. They know all the features that are used in this study and they are ready to use them, but as soon as they know that they are going to be used for academic purposes, they reconsider their attitude towards them. This refers to the association of academic things to grades, homework, assignments, success and failure. Another reason may be the lack of training for students and teachers on the use of the mobile phones for academic purposes. The introduction of this new strategy should be gradual and in small doses so that students can get familiar with it and can cope with its advantages and consequences on their achievement. The final reason is the traditional look at mobiles as violations of the discipline and distracters that take students away and affect their interaction and participation.

\section{Recommendations}

To meet the challenges of the $21^{\text {st }}$ century, technological revolution is a must for educational institutions. Among developing countries, mobile technologies as well as other technologies are developing rapidly in KSA. Students in KSA either at school or at university not only have the most up to date mobile phones, but they are also professional in using them. This situation encourages educators and instructors to think about creative ideas on how to exploit this technology in the EFL classroom. The literature and research about mobile phones is rich with practical and applicable ideas that increase motivation and engagement and offer the learners more effective ways for practicing authentic English. But while thinking about using this technology in the EFL classroom, one should keep in mind that students need much training and orientation on how to use the mobile for teaching and learning purposes. On the other hand, the academic institutions including universities and colleges should start to change the attitudes of their students towards using mobile phones for academic purposes. Another important issue is absence which certainly has negative effects on applying any strategy; Saudi students tend to absent themselves for any reason paying little or no attention to how important it is to attend classes especially while learning languages. Finally, more studies about using new technology especially mobile phones should be conducted in the Saudi environment.

\section{Conclusion}

This study reported Saudi foundation-year students' experience of using mobile phones in the EFL classroom and also surveyed their attitudes towards using them in this context. The results of the study were not clearly and sharply in favor of using mobiles for reasons teachers and students together can overcome. To avoid these reasons, the people concerned should adopt all the potential functions and capacities of mobile phones for language teaching and learning and offer the learners more effective ways for practicing English by using mobile phone devices. Instructors need to be trained in how to apply mobile technology methodically and purposefully and to have clearly designed-lesson plans. They need to present to their students the main purposes of using mobile phones in the classroom and to practice the effective ways of using them. We think that in the course of time, teachers and learners in KSA will manage to use mobile phones smartly and systematically in EFL teaching 
and learning. Mobile phones in addition to other technology devices are expected to motivate students and to change their attitudes towards the EFL classroom. This study is an initial exploration of integrating M-learning into traditional EFL teaching. Further explorations on different new ideas and academic levels are expected to generalize the M-learning approach to a broader audience.

\section{Acknowledgment}

I would like to thank the foundation -year students at King Abdulaziz University who agreed to be the sample of this study and to take the risk of being the control and the experimental groups, the instructors who helped us in conducting the study, and the Eli staff who made our job easy and my daughter who helped in typing and analyzing the questionnaire.

\section{References}

Al-Shehri, S. (2011). Context in our Pockets: Mobile Phones and Social Networking as Tools of Contextualizing Language Learning. $10^{\text {th }}$ world conference on mobile and contextual learning. Beijing, China, 2011.

Attwell, G. (2012). 25 Practical Ideas for Using Mobile Phones in the Classroom. Retrieved from http://www.pontydysgu.org/2009/11/25-practical-ideas-for-using-mobile-phones-in-the-classroom

Baleghizadeh, S., \& Oladrastam, E. (2011). The Effect of Mobile Assisted Language Learning on Grammatical Accuracy of EFL Students. The Internet and Technology in EFL/ESL, 34(2).

Begum, R. (2011). Prospect for Cell Phones as Instructional Tools in the EFL Classroom: A Case Study of Jahangirnagar University, Bangladesh. English Language Teaching, 4(1), 105-115.

Fisher, M., \& Baird, E. D. (2007). Making M-Learning Work, Utilizing Mobile Technology for Active Exploration ... Journal of Educational Technology Systems, 35(1), 3-30.

Khwaileh, F. M., \& Al-Jarrah, A. (2010). Graduate Students' Perceptions Toward Mobile-Learning (M-Learning) at the University of Jordan. International Journal of Instructional technology and Distance Learning, 7(10), $15-23$

Kolb, L. (2008). Toys to Tools: Connecting Students' Cell phones to Education. International Society for Technology in Education. The International Society for Technology Education (ISTE).

MacLean, G. (2010). Three Mobile Phone Applications for EFL Classrooms. Proceedings of World Conference on Educational Multimedia, Hypermedia and Telecommunications 2010(1). Chesapeake, VA: AACE. Retrieved from http://www.editlib.org/p/35219

Miangah T. M., \& Nezarat, A. (2012). Mobile assisted language Learning. International Journal of Distributed and Parallel Systems, 3(1), 309-319. http://dx.doi.org/10.5121/ijdps.2012.3126

Morris N. O. (2011). Using Technology in the EFL Classroom in Saudi Arabia (2011). AYMAT Individual Thesis/ SMAT IPP Collection (pp. 1-51, Paper 511). Retrieved from $\mathrm{http}: / /$ digitalcollections.sit.edu/ipp_collection/511

O'Conner. (2005). Instant Messaging: Friend or Foe of Students' Writing? New Horizon for Learning. Retrieved May 28, 2011, from http: www.newhorizon.org/strategies/literacy, o'conner, htm

Reinder H. (2010). Twenty Ideas for Using Mobile Phones in the Language Classroom. Retrieved from $\mathrm{http}: / / \mathrm{www}$. slideshare.net/hebaabosamra56/20ideasforusingmobilephonesinlanguageclassroom-1...

Sad, S. N. (2008). Using Mobile Phone Technology in EFL Class. English Teaching Forum, 46(4), 34-39.

Thornton \& Houser. (2005). Using Mobile Phones in English Education in Japan. Journal of Computer Assisted Learning, 21, 217-228. http://dx.doi.org/10.1111/j.1365-2729.2005.00129.x

Trucano, M. (2009). What do we know about using mobile phones in education? (Part 2) EDU TECH, A World Bank Blog on ICT use in Education. blogs.worldbank.org/edutech/videos/mobiles-0

Wang, F., Chen, X., \& Fang, W. (2011). Integrating Cell Phones into a Chinese High School EFL Classroom: Students' Attitudes, Technological Readiness, and Perceived Learning. Journal of Educational Technology Development and Exchange, 4(1), 91-102.

Willard G. Van De Bogart. (2011). Behavioral Aspects of Thai Students Toward Cell Phone Adoption in the Classroom. International E. Learning Conference (IEC 2012) at Muang Thong Thai. 


\section{Appendices}

\section{Appendix 1.}

\section{Details about the Ten Mobile Oriented Features Used in the Experiment}

Idea 1: Use the notes feature to collect everyday language; most mobile phones have a feature that allows them to take notes. The teacher asks students to use this feature to take notes on the English they read or hear outside of school and either present the notes to the class or send them to the teacher as a text message.

Idea 2: Use the Camera feature to take pictures of texts. One of the easiest ways to use a mobile phone for learning is to record samples of the target language by taking pictures. Students can take pictures of English texts by using the camera feature on their mobile phones.

Idea 3: Use the Voice Memo Recorder feature to record language from media outlets Most phones include a memo recording feature that can collect language samples from TV or radio. The students' collected samples give you an opportunity to analyze the language, discuss where they were collected, and provide feedback.

Ideas 4\&5: Use the Text Messaging feature to reinforce vocabulary learning. For example, you could text the words covered in class to encourage students to review them outside the school context. By sending out the words multiple times, you increase the chances that students will remember them. The Text Messaging feature can also be used for circular writing. The reality is that many students do not like to write. They associate writing in the school context with boring assignments and a punitive environment of criticism and negative feedback. In other words, the fun is missing. However, if one considers writing as any form of textual communication, it becomes clear that students actually write a lot.

Idea 6: Use the mobile phone for social networking. Like Twitter, Face book and MySpace are enormously popular social networking tools that allow groups of "friends" to meet, post messages, share pictures, and generally interact online in a myriad of ways. Most of the interaction takes place in writing, and simply asking students to use English instead of their native language produces a great deal of writing practice.

Idea 7: Use mobile phone memory to distribute listening material. Many phones have memory for graphics, photos, and music that you can use to download listening material for your students, who can in turn transfer them to their phones or other media. This could be a recording of your class, a podcast, or course listening materials.

Idea 8: Use the installed dictionaries on your mobile to look up meanings of difficult words.

Idea 9: Use the internet to use online resources for more worksheets and consolidating materials.

Idea 10: Use the mobile phone to check student comprehension and get feedback.

\section{Appendix 2.}

The Questionnaire used to see Students'Attitudes towards Mobile Learning

Dear students,

This questionnaire aims at investigating students' attitudes towards using mobile phones in teaching English. Please read each of the items well and put a tick in the right column. Your opinion is important as it makes decision makers decide whether to use mobile phones in the EFL classroom or not. Thank you in advance.

$$
\begin{aligned}
& \text { عزيزي الطالب } \\
& \text { هذه الأسنبانة تهدف إلى معرفة إتجاهات الطلاب نحو إستخدام الجوال في تعليم اللغة الأنجليزية. أرجو قر اعة الفقرات جيدا ثم وضع إثـارة في العمود }
\end{aligned}
$$

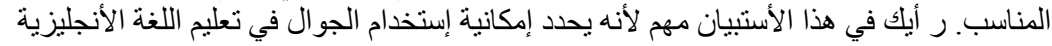

$$
\begin{aligned}
& \text { شكر ا للك مسبقا. وفقك الله لما فيه الخير. }
\end{aligned}
$$

\begin{tabular}{|c|c|c|c|c|c|c|}
\hline No & Item & $\begin{array}{l}\text { Strongly } \\
\text { Disagree } \\
\text { لأو افق بشدة }\end{array}$ & $\begin{array}{l}\text { Disagree } \\
\text { لأو افق }\end{array}$ & $\begin{array}{l}\text { Can't tell } \\
\text { لأعرف }\end{array}$ & $\begin{array}{l}\text { Agree } \\
\text { أوافق }\end{array}$ & $\begin{array}{l}\text { Strongly } \\
\text { Agree } \\
\text { أو افق بشدة }\end{array}$ \\
\hline 1 & $\begin{array}{l}\text { Using the mobile gives me a better chance to } \\
\text { learn than the lecture. } \\
\text { إستخدام الجوال يتيح لي فرصلة التعلم بشكل أفضل من المحاضرة. }\end{array}$ & & & & & \\
\hline
\end{tabular}

Appendix 2 Questionnaire for Students Attitudes 


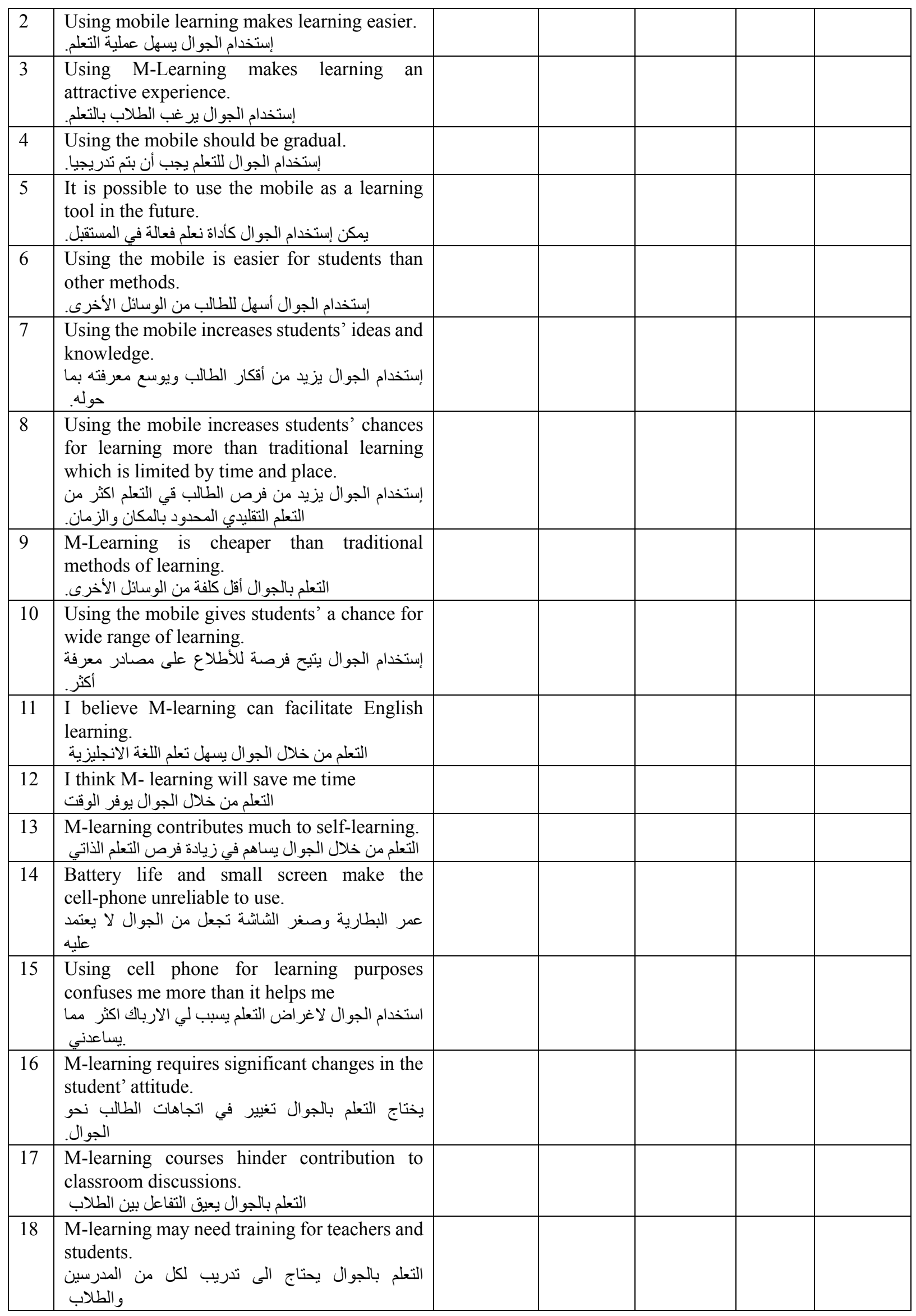




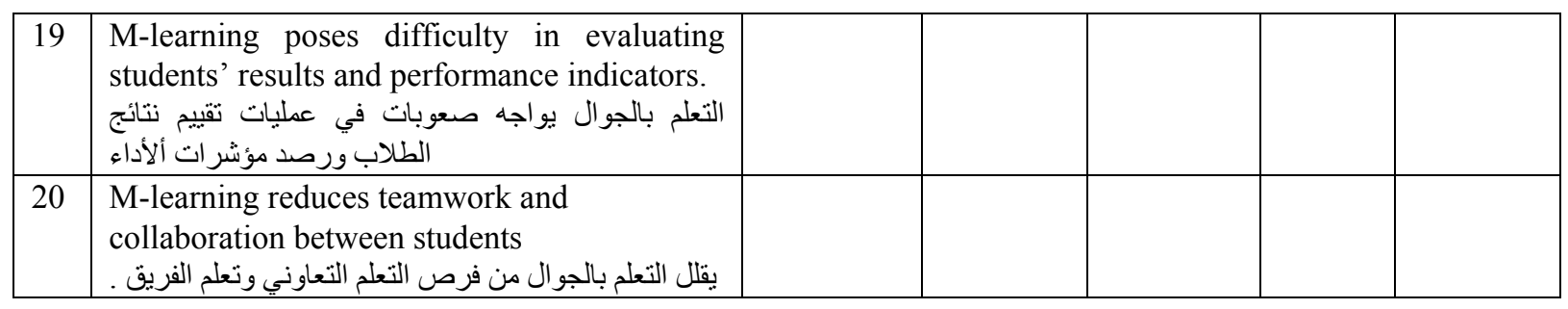

\section{Copyrights}

Copyright for this article is retained by the author(s), with first publication rights granted to the journal.

This is an open-access article distributed under the terms and conditions of the Creative Commons Attribution license (http://creativecommons.org/licenses/by/3.0/). 